\title{
Learning Strategies Predicting the Perception of Social Presence of Distance Education Students
}

\author{
Ebru KILIÇ ÇAKMAK*a, Yusuf Ziya OLPAK ${ }^{\mathrm{b}}$
}

\begin{tabular}{l} 
Article Info \\
\hline DOI: $10.14686 /$ buefad.365218 \\
\hline Article History: \\
Received $\quad 13.12 .2017$ \\
Revised $\quad 10.02 .2018$ \\
Accepted $\quad 14.02 .2018$ \\
\hline Keywords: \\
Social presence, \\
Co-presence, \\
Influence, \\
Cohesiveness, \\
Learning strategies. \\
\hline Article Type: \\
Research Article \\
\end{tabular}

\begin{abstract}
This research was planned to reveal the relationship between social presence and self-regulation in e-learning process, which is very important for distance education students. In this context, it was tried to determine the learning strategies that predict students' social presence perceptions. The research carried out according to the survey model, was carried out with the data obtained from 61 students giving appropriate answers to the questions in data collection tools. In the process of collecting the data; motivation and learning strategies scale, social presence scale and personal information form developed by the authors were used. For analyzing the data; descriptive statistics, stepwise regression analysis and one way ANOVA were used. Results of the study showed that students' common presence perceptions could be predicted with organization and help seeking, e-learners perceived influence could be predicted with three variables; organization, help seeking and effort regulation, e-learners perceived cohesiveness could be predicted with three variables; help seeking, organization and effort regulation, and e-learners perceived social presence could be predicted with three variables; organization, help seeking and effort regulation. In addition, the social presence perceptions of the students do not show a significant difference in terms of variables including gender, class level and department.
\end{abstract}

\section{Uzaktan Eğitim Öğrencilerinin Sosyal Bulunuşluk Algılarını Yordayan Öğrenme Stratejileri}

\begin{tabular}{|c|c|}
\hline \multicolumn{2}{|c|}{ Makale Bilgisi } \\
\hline \multicolumn{2}{|c|}{ DOI: $10.14686 /$ buefad.365218 } \\
\hline $\begin{array}{l}\text { Makale G } \\
\text { Geliş } \\
\text { Düzeltme } \\
\text { Kabul }\end{array}$ & $\begin{array}{l}\text { mişi: } \\
13.12 .2017 \\
10.02 .2018 \\
14.02 .2018\end{array}$ \\
\hline \multicolumn{2}{|c|}{$\begin{array}{l}\text { Anahtar Kelimeler: } \\
\text { Sosyal bulunuşluk, } \\
\text { Ortak bulunuşluk, } \\
\text { Etkileme, } \\
\text { Kaynaştırma, } \\
\text { Öğrenme stratejileri. }\end{array}$} \\
\hline \multicolumn{2}{|c|}{$\begin{array}{l}\text { Makale Türü: } \\
\text { Araştırma Makalesi }\end{array}$} \\
\hline
\end{tabular}

\begin{abstract}
$\ddot{O} \mathbf{z}$
$\mathrm{Bu}$ araștırma uzaktan eğitim öğrencileri için oldukça önemli olan sosyal bulunuşluk ve öz-düzenlemenin e-öğrenme sürecinde bir biri ile ilişkisini ortaya koymak amaciyla planlanmıştır. $\mathrm{Bu}$ bağlamda öğrencilerin sosyal bulunuşluk algılarını yordayan öğrenme stratejileri belirlenmeye çalışılmıştır. Tarama modeline göre yürütülen araştırma, kullanılan veri toplama araçlarındaki sorulara uygun şekilde yanıtlar veren 61 ögrenciden elde edilen veriler ile gerçekleştirilmiştir. Verilerin toplanmasında; güdülenme ve öğrenme stratejileri ölçeği, sosyal bulunuşluk ölçeği ve yazarlar tarafından geliştirilen kişisel bilgi formu kullanılmıştır. Verilerin çözümlenmesinde ise; betimsel istatistikler, adımsal regresyon analizi ve ilişkisiz örneklemler için tek faktörlü varyans analizi kullanılmıştır. Araştırma sonuçları öğrencilerin ortak bulunuşluk algılarının; düzenleme ve yardım isteme ile, etkileme algılarının; düzenleme, yardım isteme ve emek yönetimi ile, kaynaştırma algılarının; yardım isteme, düzenleme ve emek yönetimi ile ve son olarak sosyal bulunuşluk algılarının ise; düzenleme, yardım isteme ve emek yönetimi ile yordanabileceğini göstermiştir. Ayrıca öğrencilerin sosyal bulunuşluk algıları; cinsiyet, sınıf ve bölüm değişkenlerine göre anlamlı bir farklılık göstermemiştir.
\end{abstract}

*Corresponding Author: ekilic@gazi.edu.tr

${ }^{\text {a }}$ Prof. Dr., Dr.,Gazi University, Ankara/Turkey, http://orcid.org/0000-0002-3459-6290

b Asst. Prof. Dr.,Ahi Evran University, Kırşehir/Turkey, http://orcid.org/0000-0001-5092-252X 


\section{Introduction}

As regards distance education, which emerged as a result of social structure and the changes in needs, Moore, who first came to mind and pioneered the field, stated that distance education is a pedagogical concept rather than a simple geographical separation of students and teachers. Moore (1993) stated that the student and the teacher are always as location, sometimes as location and time, in the online or distance learning environments, and describe the psychological and communicative gap created by this separation as transactional distance. According to this theory, there are three variables, namely the degree of affecting the teacher-student relationship of transactional distance, dialogue, structure and learning autonomy.

Dialogue is developed during interactions between teachers and students (Moore, 1993). According to Moore, the dialogue and interaction concepts are very similar to each other and even they substitute each other. However, there is an important discrimination between them. Dialogue is used for identifying an interaction which has positive qualifications or for completing the interaction series and other interactions may not have this (Moore, 1993).

The structure is to structure the elements used in course design or education program by using various communication tools. The programs are structured according to the needs like copying, distribution and control. The structure expresses the flexibility or solidity related with the educational purpose of the program, education strategies and evaluation methods and it is a qualitative variable like dialogue. For example, in a course which is presented with a television program recorded previously, every second is definite and it is a course which does not include any dialogue since any input from the students is not taken. In such course, there is no change or little changes according to the individual needs of the students. However, if the same course is given with teleconference method, wide alternative replies given by the lecturers to the written messages and questions of the students, are possible. Thus, this environment includes more dialogue and less structure (Moore, 1993). In other words, the structure and dialogue are inversely proportional. When the structure increases, the transactional distance increases and when the dialogue increases transactional distance decreases as well.

Learner autonomy concept is developed for identifying the process of students in using their learning materials and programs with their own controls and own methods for reaching their purposes. Learner autonomy is the student rather than the teacher the degree to which many learners have taught in teaching/learning relationships in order to determine their learning objectives, learning experiences and assessment decisions of the learning program (Moore, 1993). In other words, it may be said that learner autonomy corresponds to the decisions of the students given for how, what, how much to learn.

As can be seen from the above definitions, these three elements (dialogue, structure, and learner autonomy) have an important place for a successful distance education experience. In addition, the advantage of distance education programs such as learning in his own learning speed and as needed from the desired place and time while it has some disadvantages such as having the students feel themselves alone in their own learning environment, communication concern with the other students and teacher, having the students to be motivated, self-disciplined. In this context, self-regulated learning (SRL) skills become important in efficient management of this process and in taking the responsibility of their own learning process in distance education.

Different researchers made different definitions related with the SRL which its effect on the learning of the students is presented with many studies on the learning of the students. Pintrich (1995) defines self-regulation as the actively managing and controlling the level of knowledge, motivation and behavior of a student for academic tasks. Schunk and Zimmerman (2008) define self-regulated learning as a process in which learners turn their minds, emotions and behaviors systematically towards learning objectives. In a study conducted by Pintrich and De Groot (1990), in the self-regulated learning process, it is mentioned that the individual must take the responsibility of his/her own learning process and manage this process efficiently. In this respect, it may be said that the SRL has an important role in conforming to the changing and developing conditions of the individuals and becoming active in lifelong learning process.

In the study of Montalvo and Torres (2004) on the current and future orientations related with the SRL, the basic specifications separating the students with self regulate skills from the students without these skills, are mentioned in six items by benefiting from the studies conducted by different researchers (Corno, 2001; Weinstein, Husman, \& Dierking, 2000; Winne, 1995; Zimmerman, 1998, 2000, 2001, 2002). These are; 
- They know how to use the cognitive strategies (repetition, elaboration and organization), which help them to attend to, transform, organize, elaborate and recover information.

- They have the skills of planning, controlling and managing the mental processes for reaching their personal goals.

- They have motivational beliefs and adaptive emotions in developing positive feelings such as joy, satisfaction and enthusiasm related with the tasks and adopting the learning purposes and academic self-efficacy perception in high level for the requirements of special learning status and learning tasks.

- In order to create favourable learning environments, they have the skills of using the current resources and time affectively.

- They show a great effort in regulation in accordance with the requirements and controlling the task and learning environment by the efficient participation method.

- They can efficiently use the strategies related with their self control for providing the continuity efforts against the stimulus which can distract attention while performing academic tasks.

In summary, SRL skills helps to describe the ways of how students approach tasks, apply strategies, monitor their performance, and interpret the outcomes of their efforts towards achieving specific learning goals. However, students need to choose and use their learning strategies appropriately in order to be self-regulating. Learning strategies are strategies that are done by students for help in obtaining, storing, recalling, and using information. Learning strategies can also be expressed as "specific actions that students use to make learning easier, faster, more fun, more self-regulated, more effective, and easier to transfer to new situations" (Oxford, 1990). In this context, various SRL strategies are suggested in the literature (Pintrich, 2000; Weinstein \& Mayer, 1986; Zimmerman, 1990). For example; Zimmerman (1990) has collected the SRL strategies in 14 categories as to be self-evaluation, organization and transformation, goal setting and planning, information seeking, record keeping, self-monitoring, environmental structuring, giving self consciousness, rehearsing and memorizing, seeking social assistance (peers, teacher, or other adults), reviewing (notes, books, or tests). In scope of this research, motivated strategies for learning questionnaire which is developed by Pintrich, Smith, Garcia, and McKeachie (1991) and was used since it is preferred mostly in the literature and provided opportunity for the determination of the learning strategies used by the students according to their own responses. The academic infrastructure of the section related with learning strategies of the questionnaire was formed of rehearsal, elaboration, organization, critical thinking, time and study environment, effort regulation, peer learning, help seeking, planning, monitoring and regulating strategies. When these factors are reviewed, it is seen that an appropriate interaction is needed among the participants for the successful usage of the learning strategies.

Distance education theorists (Garrison, 1991; Garrison, 2000; Holmberg, 1991; Moore \& Kearsley, 1996) and some researchers (Anderson \& Garrison, 1995; Harasim, 1990; Henri \& Rigault, 1996; Katz, 2000; Saba \& Shearer, 1994; Soo \& Bonk, 1998; Winn, 1999) has loaded a critical importance to the interaction by considering the economic disadvantages and incomes and the educational, motivational effect of the interaction (As cited in: Moore \& Anderson, 2003). A number of online educators and researchers have reported that interaction with others significantly and positively relates to social presence (Kim, Kwon, \& Cho, 2011; Shen, Nuankhieo, Huang, Amelung, \& Laffey, 2008; Tu \& McIsaac, 2002). In other words, to provide dialogue opportunities among all participants is very important for social presence perceptions of the participants in distance education applications.

Social presence (Lowenthal \& Dunlap, 2010) which is one of the important concepts in online learning, was first used by Short, Williams, and Christie (1976) and has been identified as the perception degree of each person in interpersonal relations (As cited in: Kim, Kwon, \& Cho, 2011). When the literature is examined, it is observed that the social presence is identified in different forms by the different researchers:

- According to Gunawardena and Zittle (1997), it is the perception degree of a person like an actual person in communication environment.

- According to Tu and McIsaac (2002), it is the measurement of the feeling of being a society which forms as the result of the students' experiences in online environment. 
- According to Kang, Choi, and Park (2007), it is the depth which is perceived by the relations between the other students and society in online learning process.

- According to Garrison (2009), the ability to identify with a group, communicate purposefully, and develop interpersonal relationships.

When the social presence definitions made by different researcher are examined, especially in the online learning environment, it is seen that the individual has an emphasis on the feeling of existence and communication with other individuals. To create social presence perception in high levels in learning environment shall help being perceived as warm and accessible for all the participants (Rourke, Anderson, Garrison, \& Archer, 2001). According to Rourke et al., (2001), the other benefit of the social presence perception is to encourage and support the cognitive and affective learning goals by making the group interactions as attractive and charming. In the studies conducted by Tu and McIsaac (2002), the dimensions of social presence has been examined with qualitative and quantitative methods and it is mentioned that the social presence is a vital elements affecting the online interaction. The results of the study conducted by Richardson and Swan (2003) for examining the social presence perception in online learning environment, shows that the social presence perception and learning perception of the students have a positive relation. In the study of Swan and Shih (2005), a significant relation is found between the social presence perception and the satisfaction in the online discussions. The results of the study conducted by Lu, Huang, Ma, and Luce (2007), shows that the social presence perception has an important effect on the learning outcomes and satisfaction of the students related with the cognitive learning, satisfactions related with the learning process and satisfactions of the participants in the activities.

As the result, besides providing opportunities for the dialogue between the student and teacher for a successful distance education, the learning materials need to be structured properly (Moore, 1993). However, in practice this becomes a very complicated issue. Because it changes according to the content, education level, students' characteristics and level of the most appropriate learner autonomy which particularly the student may apply (Moore, 1993). In addition to this, for reducing the transactional distance particularly in the distance education, to provide opportunities for dialogue may positively affect the social presence perceptions of whole participants. Furthermore, this will provide opportunities for students to use SRL skills to construct their own learning. As can be seen, SRL and social presence concepts are very important for a successful distance education program. In this context, in order to reveal the relationship between social presence and self-regulation in the e-learning process, the following research questions were sought in this research.

1. What are the learning strategies that predict the social presence perceptions of the students?

2. Do the social presence perception of the students show a significant difference in terms of gender, class level and department variables?

\section{Method}

\section{Research Design and Participants}

In scope of this research which is carried out according to survey model, 105 students who enrolled in the different distance education programs in a state university, were reached for the study. However, the research was studied with the data obtained from 61 students excluding those who have filled the data collection tools as faulty and missing. Findings related to the distribution of students in the study group according to their various characteristics are given in Table 1.

Table 1. Distribution of the Students in Study Groups According to the Various Specifications

\begin{tabular}{llll} 
& & $\mathrm{N}$ & $\%$ \\
Gender & Male & 21 & 34.43 \\
Class Level & Female & 40 & 65.57 \\
& 1 & 45 & 73.77 \\
Department & 2 & 16 & 26.23 \\
& Computer Technologies and Programming & 32 & 52.46 \\
& Business Management & 29 & 47.54 \\
\hline
\end{tabular}


As seen in Table 1, $32(\% 52.5)$ of the students in the study groups continues to the program of "Computer Technologies and Programming" and 29 (\%47.5) continues to the program of "Business Management" and the age average is 21 . The students may reach to the course contents whenever they want over the learning management system. Besides, as asynchronous, a communication may be established between the lecturer and the other students. In addition to this, an interaction may be established over Adobe Connect program with the simultaneous sessions which are held weekly. In addition to all these, there is a social exchange platform provided by the institution so that students can interact and share with each other.

\section{Data Collection Tools}

In scope of the research; the motivated strategies for learning questionnaire, social presence scale and the personal information form developed by the authors are used in data collection process.

Motivated strategies for learning questionnaire. The motivated strategies for learning questionnaire (MSLQ) was used, which was developed to assess university students' motivational orientations and their use of different learning strategies by Pintrich et al. (1991) and adapted into Turkish by Büyüköztürk, Akgün, Özkahveci, and Demirel (2004). Motivation scale is composed of 6 factors being as "intrinsic goal orientation", "extrinsic goal orientation", "task value", "control belief of learning", "self-efficacy" and "test anxiety" together with 31 items. Learning strategies scale is composed of 50 items and 9 factors in total. These factors are "rehearsal", "elaboration", "organization", "metacognitive self-regulation", "critical thinking", "help seeking", "effort regulation", "peer learning" and "time and study environment". 81 items of the MSLQ are scored on a 7 point Likert scale, from 1 (not at all true of me) to 7 (very true of me). Cronbach $\alpha$ internal consistency related to subscaled factors varies between .86 and .41. In this study, the learning strategies part of the questionnaire is used.

Social presence scale. The social presence scale which is developed by Kang et al. (2007) and adapted into Turkish by Olpak and Kılıç Çakmak (2009), was used for determining the social presence perceptions of the students. The social presence scale which its Turkish adaptation study was done, consists of 3 factors and 19 items as to be 5 items for co-presence, 7 items for influence, and 7 items for cohesiveness. All items were scored on a 5-point Likert scale ranging from 1 (strongly disagree) to 5 (strongly agree). The high point obtained from the scale shows that the individual feels existence him/herself socially in an environment. Cronbach $\alpha$ value of the social presence scale consisting of three factors; for co-presence .79 , for influence .86 and for cohesiveness .91 . Cronbach $\alpha$ value calculated for the whole scale is .94 .

Personal information form. A form was developed in order to collect data concerning features of e-learners. Questions related to students' gender, age, internet and computer use periods, etc. were included in this form. Apart from this, data related to students' departments, class level, etc. were collected from the student information system of the university.

\section{Data Analysis}

For determining the learning strategies predicting the social presence perceptions of the students, stepwise regression analysis was used. One way ANOVA was used to determine whether there is a significant difference in social presence perceptions of the students according to the various variables.

\section{Findings}

In this section, the regression analysis results performed for determining the learning strategies predicting the social presence are examined. First, the findings are presented for sub-factors of social presence and then are presented for general social presence. Finally, it is examined whether there is a significant difference in social presence perceptions of the students according to the various variables.

In this respect, for determining the learning strategies of the students which predict the social presence perceptions of the students (co-presence, influence, cohesiveness and social presence); rehearsal, elaboration, organization, critical thinking, metacognitive, time and study environment, effort regulation, peer learning and help seeking factors are added to the analysis. Table 2 (co-presence), Table 3 (influence), Table 4 (cohesiveness) and Table 5 (social presence) summarize the results of the stepwise multiple regression analysis, including the unstandardized regression coefficient $(B)$, the standard error $\left(\mathrm{SE}_{\mathrm{B}}\right)$, the standardized regression coefficient $(\beta), \mathrm{R}^{2}$ and adjusted $\mathrm{R}^{2}$. 
Table 2. Summary of Stepwise Regression Analysis for Variables Predicting Students' Co-presence

\begin{tabular}{llll}
\hline Model & $\mathrm{B}$ & $\mathrm{SE}_{\mathrm{B}}$ & $\beta$ \\
\hline Model 1 & .447 & .119 & .441 \\
Organization & & & $\begin{array}{l}\mathrm{R}^{2}=.194 \\
\text { Adjusted } \mathrm{R}^{2}=.180 \\
\mathrm{R}=.441^{*}\end{array}$ \\
Model 2 & & & .322 \\
Organization & & & .321 \\
Help Seeking & .327 & .121 & $\mathrm{R}^{2}=.283$ \\
& .393 & .146 & Adjusted $\mathrm{R}^{2}=.258$ \\
& & & $\mathrm{R}=.532^{*}$ \\
\hline $\mathrm{p}<0.01$ & & &
\end{tabular}

The regression analysis (Table 2) shows that e-learners perceived co-presence could be predicted with two variables: Organization and help seeking. The rest of the variables entered did not significantly contribute to predicting students' co-presence. The first model shows that student co-presence can be predicted by the organization, which explains $19 \%$ of the variance $\left(\mathrm{R}=.441, \mathrm{~F}_{(1,59)}=14.215, \mathrm{p}<.01\right)$. The second model with two predictors indicates that approximately $10 \%$ of the variance was increased by adding the second predictor, the help seeking. Therefore, it was concluded that the two-predictor model was appropriate for predicting the level of student co-presence $\left(\mathrm{R}=.532, \mathrm{~F}_{(2,58)}=11.457, \mathrm{p}<.01\right)$.

Table 3. Summary of Stepwise Regression Analysis for Variables Predicting Students' Influence

\begin{tabular}{|c|c|c|c|}
\hline Model & B & $\mathrm{SE}_{\mathrm{B}}$ & $\beta$ \\
\hline $\begin{array}{l}\text { Model } 1 \\
\text { Organization }\end{array}$ & .592 & .147 & $\begin{array}{l}.466 \\
\mathrm{R}^{2}=.217 \\
\text { Adjusted } \mathrm{R}^{2}=.204 \\
\mathrm{R}=.466^{*}\end{array}$ \\
\hline $\begin{array}{l}\text { Model } 2 \\
\text { Organization } \\
\text { Help Seeking }\end{array}$ & $\begin{array}{l}.474 \\
.388\end{array}$ & $\begin{array}{l}.153 \\
.185\end{array}$ & $\begin{array}{l}.372 \\
.253 \\
\mathrm{R}^{2}=.272 \\
\text { Adjusted } \mathrm{R}^{2}=.247 \\
\mathrm{R}=.521^{*}\end{array}$ \\
\hline $\begin{array}{l}\text { Model } 3 \\
\text { Organization } \\
\text { Help Seeking }\end{array}$ & $\begin{array}{l}.668 \\
.425\end{array}$ & $\begin{array}{l}.170 \\
.179\end{array}$ & $\begin{array}{l}.525 \\
.277\end{array}$ \\
\hline Effort Regulation & -.419 & .182 & $\begin{array}{l}-.298 \\
\mathrm{R}^{2}=.334 \\
\text { Adjusted } \mathrm{R}^{2}=.299 \\
\mathrm{R}=.578 *\end{array}$ \\
\hline
\end{tabular}

$* \mathrm{p}<0.01$

The regression analysis (Table 3) shows that e-learners perceived influence could be predicted with three variables: Organization, help seeking and effort regulation. The rest of the variables entered did not significantly contribute to predicting students perceived influence level. The first model shows that student influence can be predicted by the organization, which explains $22 \%$ of the variance $\left(\mathrm{R}=.466, \mathrm{~F}_{(1,59)}=16.330, \mathrm{p}<.01\right)$. The second 
model with two predictors indicates that approximately $5 \%$ of the variance was increased by adding the second predictor, the help seeking $\left(\mathrm{R}=.521, \mathrm{~F}_{(2,58)}=10.830, \mathrm{p}<.01\right)$. The third model with three predictors indicates that approximately $6 \%$ of the variance was increased by adding the third predictor, the effort regulation $\left(\mathrm{R}=.578, \mathrm{~F}_{(3 \text {, }}\right.$ $57)=9.533, \mathrm{p}<.01)$. Therefore, it was concluded that the three-predictor model was appropriate for predicting the level of student level of perceived influence.

Table 4. Summary of Stepwise Regression Analysis for Variables Predicting Students' Cohesiveness

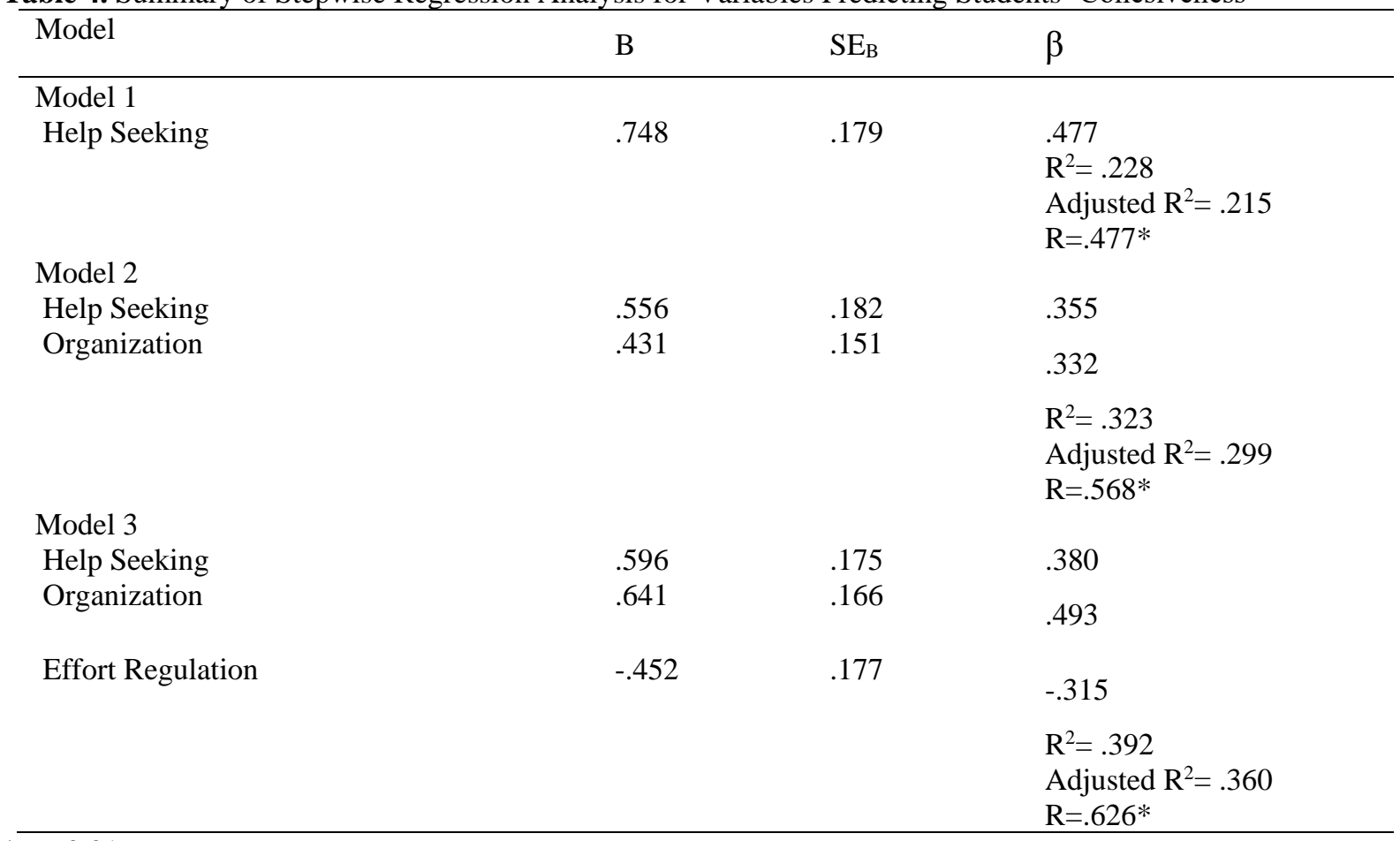

$* \mathrm{p}<0.01$

The regression analysis (Table 4) shows that e-learners perceived cohesiveness could be predicted with three variables: Help seeking, organization and effort regulation. The rest of the variables entered did not significantly contribute to predicting students perceived cohesiveness level. The first model shows that student cohesiveness can be predicted by the help seeking, which explains $23 \%$ of the variance $\left(\mathrm{R}=.477, \mathrm{~F}_{(1,59)}=17.389, \mathrm{p}<.01\right)$. The second model with two predictors indicates that approximately $9 \%$ of the variance was increased by adding the second predictor, the organization $\left(\mathrm{R}=.568, \mathrm{~F}_{(2,58)}=13.824, \mathrm{p}<.01\right)$. The third model with three predictors indicates that approximately $7 \%$ of the variance was increased by adding the third predictor, the effort regulation $\left(\mathrm{R}=.626, \mathrm{~F}_{(3,57)}=12.254, \mathrm{p}<.01\right)$. Therefore, it was concluded that the three-predictor model was appropriate for predicting the level of student level of perceived cohesiveness.

Table 5. Summary of Stepwise Regression Analysis for Variables Predicting Students' Social Presence

\begin{tabular}{|c|c|c|c|}
\hline Model & B & $\mathrm{SE}_{\mathrm{B}}$ & $\beta$ \\
\hline \multicolumn{4}{|l|}{ Model 1} \\
\hline Organization & 1.640 & .390 & $\begin{array}{l}.480 \\
\mathrm{R}^{2}=.231 \\
\text { Adjusted } \mathrm{R}^{2}=.218 \\
\mathrm{R}=.480 *\end{array}$ \\
\hline \multicolumn{4}{|l|}{ Model 2} \\
\hline Organization & 1.232 & .398 & .361 \\
\hline Help Seeking & 1.337 & .480 & .324 \\
\hline
\end{tabular}




\begin{tabular}{|c|c|c|c|}
\hline & & & $\begin{array}{l}\mathrm{R}^{2}=.321 \\
\text { Adjusted } \mathrm{R}^{2}=.298 \\
\mathrm{R}=.567^{*}\end{array}$ \\
\hline \multicolumn{4}{|l|}{ Model 3} \\
\hline Organization & 1.752 & .440 & .513 \\
\hline Help Seeking & 1.436 & .463 & .348 \\
\hline \multirow[t]{2}{*}{ Effort Regulation } & -1.120 & .469 & -.297 \\
\hline & & & $\begin{array}{l}\mathrm{R}^{2}=.383 \\
\text { Adjusted } \mathrm{R}^{2}=.351 \\
\mathrm{R}=.619 *\end{array}$ \\
\hline
\end{tabular}

$* \mathrm{p}<0.01$

Finally, the regression analysis (Table 5) shows that e-learners perceived social presence could be predicted with three variables: Organization, help seeking and effort regulation. The rest of the variables entered did not significantly contribute to predicting students perceived social presence level. The first model shows that student social presence can be predicted by the organization, which explains $23 \%$ of the variance $\left(\mathrm{R}=.480, \mathrm{~F}_{(1,59)}=\right.$ $17.687, \mathrm{p}<.01)$. The second model with two predictors indicates that approximately $9 \%$ of the variance was increased by adding the second predictor, the help seeking $\left(\mathrm{R}=.567, \mathrm{~F}_{(2,58)}=13.741, \mathrm{p}<.01\right)$. The third model with three predictors indicates that approximately $6 \%$ of the variance was increased by adding the third predictor, the effort regulation $\left(\mathrm{R}=.619, \mathrm{~F}_{(3,57)}=11.800, \mathrm{p}<.01\right)$. Therefore, it was concluded that the three-predictor model was appropriate for predicting the level of student level of perceived social presence.

The scores the students receive from the social presence scale; one-way ANOVA analysis was used to find out whether there was a meaningful difference according to gender, class level and department (see Table 6, Table 7 and Table 8).

Table 6. One-Way ANOVA Results for Gender

\begin{tabular}{lccccc}
\hline Source of Variance & Sum of Squares & df & Mean Square & F & p \\
Between Groups & 20.464 & 1 & 20.464 & .075 & .785 \\
Within Groups & 16060.552 & 59 & 272.213 & & \\
Total & 16081.016 & 60 & & & \\
\hline
\end{tabular}

Table 7. One-Way ANOVA Results for Class Level

\begin{tabular}{lccccc}
\hline Source of Variance & Sum of Squares & $\mathrm{df}$ & Mean Square & $\mathrm{F}$ & $\mathrm{p}$ \\
Between Groups & 65.879 & 1 & 65.879 & .243 & .624 \\
Within Groups & 16015.137 & 59 & 271.443 & & \\
Total & 16081.016 & 60 & & & \\
\hline
\end{tabular}

Table 8. One-Way ANOVA Results for Department

\begin{tabular}{lccccc}
\hline Source of Variance & Sum of Squares & df & Mean Square & F & p \\
Between Groups & 673.591 & 1 & 673.591 & 2.579 & .114 \\
Within Groups & 15407.426 & 59 & 261.143 & & \\
Total & 16081.016 & 60 & & & \\
\hline
\end{tabular}

For determining whether there is a significant difference in social presence perceptions of the students according to the various variables, one-way ANOVA was used (see Table 6, Table 7 and Table 8). According to the findings, social presence perceptions do not show a significant difference according to gender, class level and department variable.

\section{Discussion and Conclusion}

The results of stepwise regression analysis results performed for determining the learning strategies predicting the social presence perception of the students, are as follows. E-learners perceived co-presence could be predicted 
with two variables; organization and help seeking, e-learners perceived influence could be predicted with three variables; organization, help seeking and effort regulation, e-learners perceived cohesiveness could be predicted with three variables; help seeking, organization and effort regulation, and e-learners perceived social presence could be predicted with three variables; organization, help seeking and effort regulation. In addition, the social presence perceptions of the students did not show any significant difference according to gender, class level and department variables.

The interpretation of learning strategies that perceive the perceptions of the social presence of subordinate factors and social presence of learners will be better understood by knowing what the sub-factors of social presence mean. The three sub-factors of the social presence scale used in the research are defined by Olpak and Kılıç Çakmak (2009) as follows.

- Co-presence is to have the individuals to feel themselves as the part of the group and not to feel excluded from the group, to consider other people and and that they are aware of each other,

- Influence, is to have the individuals understand each other, present ideas as independently from each other and help each other,

- Cohesiveness expresses the positive interactions of the individuals, to have the individual find a chance for making contributions to the studies and feel themselves belonging to the group.

Organization strategies are strategies that assist students in choosing appropriate knowledge and constructing knowledge by linking information (Pintrich et al., 1991). Finding the main idea of the paragraphs is an example of organization strategies. Because of these characteristics stated in the organization strategies, perceptions of students' sub-factors of social presence and social presence perceptions may have been predicted.

The help seeking strategies are the strategies related with help seeking and determining the necessity of taking help when necessary (Pintrich et al., 1991). In this context, assistance from other students or instructors may be requested. For helping students when required; phone, chat, e-mail and video environments can be offered. Therefore, the students know that they are not alone in case of a problem and someone shall help them (Lehman \& Conceição, 2010). There is a large body of research indicates that peer help, peer tutoring, and individual teacher assistance facilitate student achievement. Because of these characteristics, the help seeking strategies may have predicted the social presence perceptions and the perceptions related with the sub-factors of social presence of the students.

Effort regulation strategies are the strategies which provide the student to maintain his attention and effort. It is important for academic success for providing the continuity in working in hard missions and usage of the learning strategies (Pintrich et al., 1991). The cooperative learning activities where the students may compare notes with each other, may increase the social presence perception by increasing the student-student interaction (Rovai, 2000, 2002; Whiteman, 2002). However, the learning activities such as group working, group discussions, brain storming sessions, group tasks, group projects and online group discussions must be pre-planned for increasing the social presence perception (Vrasidas \& McIsaac, 2000). In this context, the effort regulation strategies may have predicted the social presence perceptions and perceptions related with the sub-factors (influence and cohesiveness) of the social presence of the students.

The population of this research was formed from the students who study in the vocational high school in a state university. Therefore, for the generalizability of the research findings, it is suggested that more comprehensive researches must be carried out including the students in different distance education vocational high schools. In addition to these, the researchers mentioned about the importance of self-regulate in each education level. Because it is observed that the students with self-regulate skill, have high cognitive awareness and self-efficacy level and actualize an efficient time and effort management. In this context, to conduct studies including students with different education level (associate degree, bachelor degree and post-graduate degree) in the future researches. 


\title{
Uzaktan Eğitim Öğrencilerinin Sosyal Bulunuşluk Algılarını Yordayan Öğrenme Stratejileri
}

\begin{abstract}
Giriş
Toplumsal yapı ve ihtiyaçlardaki değişimlerin bir sonucu olarak ortaya çıkan uzaktan eğitim ile ilgili olarak, ilk akla gelen ve alanın öncülerinden olan Moore, uzaktan eğitimin, öğrenci ve öğretmenin basit bir coğrafik ayrılığından çok, pedagojik bir kavram olduğunu belirtmiştir. Moore (1993) öğrenci ve öğretmenin çevrimiçi veya uzaktan öğrenme ortamlarında her zaman mekan olarak, bazen de hem mekan hem de zaman olarak ayrı olduğunu belirtmiş ve bu ayrılığın oluşturduğu psikolojik ve iletişimsel boşluğu işlemsel uzaklık olarak nitelemiştir. Bu teoriye göre, işlemsel uzaklığın öğretmen-öğrenci ilişkisini etkileme derecesi; diyalog, yapı ve öğrenen özerkliği olarak adlandırılan üç değişkene bağlıdır.

Diyalog, öğretmenler ve öğrenciler arasında derste ortaya çıkan etkileşimler sırasında geliştirilir (Moore, 1993). Moore'a göre diyalog ve etkileşim kavramları birbirlerine çok benzerdirler ve hatta birbirlerinin yerine de kullanılmaktadırlar. Ancak aralarında önemli bir ayrım vardır. Diyalog olumlu niteliklere sahip bir etkileşimi veya etkileşimler serisini tanımlamak için kullanılır ve diğer etkileşimler buna sahip olmayabilirler (Moore, 1993).

Yapı ise ders tasarımında kullanılan elemanların veya öğretim programının çeşitli iletişim araçları kullanılarak yapılandırılmasıdır. Programlar yapım, kopyalama, dağıtım ve kontrol gibi ihtiyaçlara göre yapılandırılırlar. Yapı programın eğitimsel amaçları, öğretim stratejileri ve değerlendirme yöntemleri ile ilgili esneklik veya katılığı ifade eder ve tıpkı diyalog gibi nitel bir değişkendir. Mesela; daha önceden kayıt edilerek televizyon programı ile sunulan bir derste, her saniye neler olacağı bellidir ve öğrencilerden herhangi bir girdi alınamayacağından diyalog içermeyen bir derstir. Böyle bir derste öğrencilerin bireysel ihtiyaçlarına göre değişiklikler yoktur ya da çok azdır. Ancak aynı ders telekonferans yöntemi ile verilirse öğrencilerin sorularına ve yazılı gönderilerine öğretim elemanlarının çok geniş alternatif yanıtlar vermelerine olanak sağlanmış olur. Böylece bu ortam daha fazla diyalog ve daha az yapı içermiş olur (Moore, 1993). Başka bir ifadeyle yapı ve diyalog ters orantılıdır. Yapı arttığında işlemsel uzaklık artar ve diyalog arttığında da işlemsel uzaklık azalır.
\end{abstract}

Öğrenen özerkliği kavramı ise; öğrencilerin amaçlarına ulaşmak için, kendi yöntemlerini kullanarak, kendi kontrolleri ile öğrenme materyallerini ve programlarını kullanmaları sürecini tanımlamak için geliştirilmiştir. Öğrenen özerkliği öğretme/öğrenme ilişkisinde amaçları, öğrenme deneyimlerini ve öğrenme programının değerlendirme kararlarını belirlemede öğretmenden çok öğrencinin olma derecesidir (Moore, 1993). Başka bir ifadeyle öğrenen özerkliğinin, öğrencilerin; neyi, nasıl ve ne kadar öğreneceğine dair vermesi gereken kararlara karşılık geldiği söylenebilir.

Yukarıda yapılan tanımlardan da görüleceği üzere, başarılı bir uzaktan eğitim deneyimi için bu üç elemanın (diyalog, yapı ve öğrenen özerkliği) önemli bir yere sahip olduğu söylenebilir. Uzaktan eğitim programlarının; öğrencilerin istediği zaman, istediği yerden, kendi öğrenme hızında ve ihtiyaç duyduğu kadar öğrenmesine olanak sağlaması gibi avantajlarının yanında; öğrencilerin çalıştıkları öğrenme ortamlarında kendilerini yalnız hissetmeleri, diğer öğrenciler ve öğretim elemanı ile iletişim kaygısı, öğrencilerin güdülenmiş, öz denetimli ve öz disiplinli olmalarının gerekmesi gibi dezavantajları bulunmaktadır. Bu bağlamda özellikle uzaktan eğitim alan öğrencilerin kendi öğrenme sürecinin sorumluluğunu almasında ve bu süreci etkin olarak yönetmesinde, öz düzenleyici öğrenme becerileri de önemli hale gelmektedir.

Öğrencilerin öğrenmeleri üzerindeki etkisi birçok çalışma ile ortaya konulmuş olan öz düzenleyici öğrenme ile ilgili farklı araştırmacılar farklı tanımlamalar yapmışlardır. Pintrich (1995) öz düzenlemeyi; öğrencinin akademik görevler için bilişini, güdülenme düzeyini ve davranışlarını kontrol ederek aktif olarak düzenlemesi olarak tanımlanmaktadır. Schunk ve Zimmerman (2008) ise öz düzenleyici öğrenmeyi; öğrencilerin düşüncelerini, duygularını ve davranışlarını sistemli olarak öğrenme hedeflerine ulaşmaya yönlendirdiği süreç olarak tanımlamıştır. Pintrich ve De Groot (1990) tarafından yapılan çalışmada da öz düzenleyici öğrenme sürecinde, bireyin kendi öğrenme sürecinin sorumluluğunu alması ve bu süreci etkin olarak yönetmesi gerektiği belirtilmiştir. Bu bağlamda bireylerin her gün değişen ve gelişen şartlara ayak uydurmalarında ve hayat boyu ögrenme sürecinde aktif olabilmelerinde öz düzenleyici öğrenmenin önemli bir yere sahip olduğu söylenebilir.

Montalvo ve Torres (2004) tarafından öz düzenleyici öğrenme ile ilgili mevcut ve gelecek yönelimler ile ilgili yapılan çalışmada, farklı araştırmacılar (Corno, 2001; Weinstein, Husman ve Dierking, 2000; Winne, 1995; Zimmerman, 1998, 2000, 2001, 2002) tarafından yapılan çalışmalardan yararlanılarak, öz düzenleme becerilerine sahip öğrencileri, bu becerilerden yoksun olan öğrencilerden ayıran temel özellikler altı madde de belirtilmiştir. Bunlar; 
- Bilgiyi dönüştürmede, organize etmede, ayrıntılandırmada ve iyileştirmede bilişsel stratejileri (tekrar, ayrıntılandırma ve düzenleme) nasıl kullanacaklarını bilirler.

- Kişisel amaçlarına ulaşmak için bilişsel süreçlerini planlama, kontrol etme ve yönetme becerisine sahiptirler.

- $\quad$ Özel öğrenme durumları ve öğrenme görevlerinin gereklilikleri için; yüksek düzeyde akademik öz yeterlilik algısı, öğrenme amaçlarını benimseme ve görevlere ilişkin eğlence, doyum ve isteklilik gibi olumlu duygular geliştirme konusunda motivasyonel inançlara ve uyarlanabilir duygulara sahiptirler.

- Uygun bir öğrenme ortamı yaratabilmek için ortamda var olan kaynakları ve zamanı etkili kullanabilme becerisine sahiptirler.

- Sürece etkin katılım yoluyla, öğrenme ortamını ve görevini kontrol etme ve gereksinimleri doğrultusunda düzenleme konusunda büyük bir çaba gösterirler.

- Akademik görevler esnasında, odaklanabilmek ve dikkat dağıtabilecek uyarıcılara karşı çabanın sürdürülmesini sağlayabilmek için iradeleri ile ilgili stratejileri etkin olarak kullanabilirler.

Özetle, öz düzenleyici öğrenme becerileri belirli öğrenme amaçlarının başarılmasına yönelik olarak öğrencilerin görevlerine nasıl yaklaştıklarını, uyguladıkları stratejileri, performanslarını izlemeyi ve çabalarının çıktılarının yorumlanmasının tanımlanmasına yardımcı olur. Ancak, öğrencilerin öz düzenleyici olabilmeleri için, öğrenme stratejilerini uygun bir şekilde seçmeleri ve kullanmaları gerekmektedir. Öğrenme stratejileri ise; bilginin elde edilmesi, depolanması, geri çağrılması ve kullanılmasında yardım için öğrenciler tarafından işe koşulan stratejilerdir. Öğrenme stratejileri, öğrencilerin öğrenmeyi kolay, hızlı, daha eğlenceli, daha öz denetimli, daha etkili ve yeni durumlara daha kolay transfer edilebilir hale getirmeleri için kullandıkları özel eylemlerdir şeklinde de ifade edilebilir (Oxford, 1990). Bu bağlamda literatürde çeşitli öz düzenleyici öğrenme stratejileri önerilmektedir (Pintrich, 2000; Weinstein ve Mayer, 1986; Zimmerman, 1990). Örneğin Zimmerman (1990), özdüzenleyici öğrenme stratejilerini; öz-değerlendirme, düzenleme ve dönüştürme, hedef belirleme ve planlama, bilgi arama, kayıt tutma, kendini izleme, çevresel yapılandırma, kendini verme, tekrarlama ve ezberleme, sosyal yardım arama, notların kitapların veya sınavların gözden geçirilmesi olmak üzere 14 kategoride toplamıştır. Bu araştırma kapsamında ise öğrencilerin kullandıkları öğrenme stratejilerinin kendi yanıtlarına göre belirlenmesine olanak sağlayan ve alanyazında da sıklıkla kullanılan bir araç olması nedeni ile Pintrich, Smith, Garcia ve McKeachie (1991) tarafından geliştirilen güdülenme ve öğrenme stratejileri ölçeği kullanılmıştır. Ölçeğin öğrenme stratejileri bölümünün kuramsal altyapısı, bilişsel stratejiler ana bileşeninde yer alan yineleme, açımlama, düzenleme ve eleştirel düşünme stratejileri, metabilişsel stratejiler ana bileşenini oluşturan planlama, izleme ve düzenleme ile kaynak yönetimi ana bileşeninde yer alan; zaman ve çalışma ortamı, emek yönetimi, akran iş birliği ve yardım arama faktörlerinden oluşmaktadır. Bu faktörler ayrıntılı olarak incelendiğinde, öğrenme stratejilerinin başarılı bir şekilde kullanılabilmesi için, katılımcılar arasında uygun bir etkileşime ihtiyaç duyulduğu görülmektedir.

Uzaktan eğitim teorisyenleri (Garrison, 1991; Garrison, 2000; Holmberg, 1991; Moore ve Kearsley, 1996) ve farklı araştırmacılar (Anderson ve Garrison, 1995; Harasim, 1990; Henri ve Rigault, 1996; Katz, 2000; Saba ve Shearer, 1994; Soo ve Bonk, 1998; Winn, 1999) etkileşimin motivasyonel, eğitsel, etkisi ile ekonomik olarak artılarına ve eksilerine odaklanarak etkileşime kritik bir önem yüklemişlerdir (Akt: Moore ve Anderson, 2003). Bazı araştırmacılar ise, başkalarıyla etkileşimin önemli ölçüde ve pozitif olarak sosyal bulunuşluk ile ilişkili olduğunu belirtmişlerdir (Kim, Kwon ve Cho, 2011; Shen, Nuankhieo, Huang, Amelung ve Laffey, 2008; Tu ve McIsaac, 2002). Başka bir ifadeyle uzaktan eğitim uygulamalarında tüm katılımcılar arasında diyalog firsatları sağlanması, katılımcıların sosyal bulunuşluk algıları için de önemlidir.

Çevrimiçi öğrenmedeki önemli kavramlardan biri olan sosyal bulunuşluk (Lowenthal ve Dunlap, 2010) ilk olarak; Short, Williams ve Christie (1976) tarafından kullanılmış olup, "kişiler arası ilişkilerde her bir kişinin algılanış derecesidir" şeklinde tanımlanmıştır (Akt: Kim, Kwon ve Cho, 2011). Alanyazın tarandığında sosyal bulunuşluğun farklı araştırmacılar tarafından farklı şekillerde tanımlandığı görülmektedir:

- Gunawardena ve Zittle'ye (1997) göre, bireyin iletişim ortamında gerçek bir insan gibi algılanma derecesidir. 
- Tu ve McIsaac'a (2002) göre, çevrimiçi ortamda öğrenci deneyimleri sonucu oluşan topluluk olma duygusunun ölçüsüdür.

- Kang, Choi ve Park'a (2007) göre, çevrimiçi öğrenme sürecinde diğer öğrenciler ve toplulukla olan ilişkilerin algılanan derinliğidir.

- Garrison'a (2009) göre ise; katılımcıların toplulukla birlikte kendilerini tanıtabilmeleri için, güvenilir bir çevrede amaçlı olarak iletişim kurabilme ve kendi kişisel özelliklerini yansıtarak, kişiler arası ilişkiler geliştirebilme yeteneğidir.

Farklı araştırmacılar tarafından yapılan sosyal bulunuşluk tanımları incelendiğinde, özellikle çevrimiçi öğrenme ortamlarında bireylerin kendilerini var hissetmesi ve diğer bireylerle iletişim kurabilme derecesine vurgu yapıldığı görülmektedir. Öğrenme ortamında yüksek seviyelerde sosyal bulunuşluk algısının yaratılması ortamın bütün katılanlar için sıcak ve ulaşılabilir olarak algılanmasına yardımcı olacağından (Rourke ve diğerleri, 2001) önemlidir. Rourke ve diğerleri, (2001)'ne göre sosyal bulunuşluk algısının diğer bir yararı ise, grup etkileşimlerini; çekici, cazip ve yapmaya değer hale getirerek, bilişsel ve duyuşsal öğrenme hedeflerini teşvik etmesi, sürdürmesi ve desteklemesidir. Sosyal bulunuşluk ile ilgili yapılan çalışmalar incelendiğinde; sosyal bulunuşluğun çevrimiçi etkileşimi etkileyen hayati bir eleman olduğu (Tu ve McIsaac, 2002), sosyal bulunuşluk algısı ile öğrencilerin öğrenme algılarının pozitif ilişkiye sahip olduğu (Richardson ve Swan, 2003), sosyal bulunuşluk algısı ile çevrimiçi tartışmalardaki memnuniyet arasında anlamlı bir ilişki olduğu (Swan ve Shih, 2005) ve sosyal bulunuşluk algısının; öğrencilerin bilişsel öğrenmeleri, öğrenme süreci ile ilgili memnuniyetleri, etkinliklerdeki katılımcılar ile ilgili memnuniyetleri ve öğrenme çıtıları üzerinde önemli bir etkiye sahip olduğu (Lu, Huang, Ma ve Luce, 2007) belirtilmiştir.

Sonuç olarak başarılı bir uzaktan eğitim deneyimi için, öğretmen ve öğrenci arasında diyalog için uygun firsatlar sağlanmasının yanı sıra, öğrenme materyallerinin uygun bir şekilde yapılandırmasına da ihtiyaç vardır (Moore, 1993). Ancak uygulamada bu oldukça karmaşık bir konu haline gelir. Çünkü neyin uygun olduğu; içeriğe, öğretim seviyesine, öğrenci özelliklerine ve özellikle de öğrencilerin uygulayabileceği en uygun özerklik seviyesine göre değişir (Moore, 1993). Bununla beraber özellikle çevrimiçi uzaktan eğitimde işlemsel uzaklığı azaltmak için diyalog fırsatlarının sağlanması, etkileşimi artıracağından tüm katılımcıların sosyal bulunuşluk algılarını da olumlu yönde etkileyebilir. Ayrıca, bu durum öğrencilerin kendi öğrenmelerini yapılandırmaları için öz düzenleyici öğrenme becerilerini kullanabilecekleri firsatlar sağlayacaktır. Görüldüğü üzere öz düzenleyici öğrenme ve sosyal bulunuşluk kavramları başarılı bir uzaktan eğitim programı için oldukça önemlidir. Bu bağlamda sosyal bulunuşluk ve öz-düzenlemenin e-öğrenme sürecinde birbiri ile ilişkisini ortaya koymak amacıyla planlanan bu araştırmada aşağıda belirtilen araştırma sorularına yanıt aranmıştır.

1. Öğrencilerin sosyal bulunuşluk algılarını yordayan öğrenme stratejileri hangileridir?

2. Öğrencilerin sosyal bulunuşluk algıları; cinsiyet, sınıf ve bölüm değişkenlerine göre anlamlı farklılık göstermekte midir?

\section{Yöntem}

\section{Araştırma Modeli ve Katılımcılar}

Tarama modeline göre yürütülen bu araştırma kapsamında, bir devlet üniversitesindeki farklı uzaktan eğitim programlarına kayıtlı 105 öğrenciye ulaşılmıştır. Ancak, araştırma kapsamında kullanılan veri toplama araçlarını eksik ve hatalı dolduranlar araştırma kapsamı dışında bırakılarak 61 öğrenciden elde edilen veriler ile çalışılmıştır. Çalışma grubundaki öğrencilerin çeşitli özelliklerine göre dağılımlarına ilişkin bulgular Tablo 1'de verilmiştir.

Tablo 1. Çalışma Grubundaki Öğrencilerin Çeşitli Özelliklerine Göre Dağılımları

\begin{tabular}{llll}
\hline & & $\mathrm{N}$ & $\%$ \\
\hline \multirow{2}{*}{ Cinsiyet } & Erkek & 21 & 34.43 \\
\multirow{2}{*}{ Sinıf } & Kadın & 40 & 65.57 \\
& 1 & 45 & 73.77 \\
Bölüm & 2 & 16 & 26.23 \\
& Bilgisayar Teknolojileri ve Programlama & 32 & 52.46 \\
& İşletme Yönetimi & 29 & 47.54 \\
\hline
\end{tabular}


Tablo 1'de de görüldüğü gibi, katılımcıların 32'si (\%52.5) "Bilgisayar Teknolojileri ve Programlama", 29'u (\%47.5) ise "İ̧sletme Yönetimi" programına devam etmektedir ve yaş ortalamaları 21'dir. Ayrıca, öğrenciler istedikleri zaman öğrenme yönetim sistemi üzerinden ders içeriklerine ulaşabilmektedirler. Eşzamansız olarak öğretim elemanı ve diğer öğrenciler ile iletişim kurabilmektedirler. Bunun yanı sıra haftalık olarak, Adobe Connect programı üzerinden eşzamanlı gerçekleştirilen oturumlarla öğretim elemanı ve diğer öğrenciler ile etkileşim kurabilmektedirler. Tüm bunlara ek olarak, öğrencilerin kendi aralarında etkileşime girebilmeleri ve paylaşımlarda bulunabilmeleri için, kurum tarafından sağlanan bir sosyal paylaşım platformu da bulunmaktadır.

\section{Veri Toplama Araçları}

Araştırma kapsamında verilerin toplanmasında; güdülenme ve öğrenme stratejileri ölçeği, sosyal bulunuşluk ölçeği ve yazarlar tarafından geliştirilen kişisel bilgi formu kullanılmıştır.

Güdülenme ve ögrrenme stratejileri ölçeği. Pintrich ve diğerleri (1991) tarafindan, öğrencilerin motivasyon yönelimlerini ve kullandıkları farklı öğrenme stratejilerini değerlendirmek için geliştirilen güdülenme ve öğrenme stratejileri ölçeği Büyüköztürk, Akgün, Özkahveci ve Demirel (2004) tarafından Türkçe’ye uyarlanarak geçerlik güvenirlik çalışmaları yapılmıştır. Araştırmada yürütülen doğrulayıcı ve açımlayıcı faktör analizleri sonucunda güdülenme ve öğrenme stratejileri ölçeği; yedili Likert tipte, 81 madde ve 15 alt faktörden (güdülenme ölçeği ile ilgili 6 faktör ve öğrenme stratejileri ölçeği ölçeği ile ilgili 9 faktör) oluşmuştur. Ölçeğin Türkçe'ye uyarlanmış halindeki maddelerin Cronbach $\alpha$ değerleri 0.41 ile 0.86 arasında değişmektedir. Türkçe ve İngilizce formlarından elde edilen bilgiye göre toplam puanlar arası korelasyon katsayısı ise 0.85 'tir. Bu çalışmada ölçeğin öğrenme stratejileri bölümü kullanılmıştır.

Sosyal bulunuşluk ölçeği. Öğrencilerin sosyal bulunuşluk algılarını belirlemek amacıyla Kang ve diğerleri (2007) tarafindan geliştirilen ve Olpak ve Kılıç Çakmak (2009) tarafindan Türkçe'ye uyarlanan sosyal bulunuşluk ölçeği kullanılmıştır. Uyarlama çalışması yapılan sosyal bulunuşluk ölçeği beşli Likert tipte olup, ortak bulunuşluk (5 madde), etkileme ( 7 madde) ve kaynaştırma ( 7 madde) olmak üzere, 3 faktör ve 19 maddeden oluşmaktadır. Ölçekten elde edilen puanın yüksek olması bireyin ortamda kendini sosyal olarak var hissettiğini göstermektedir. Üç faktörden oluşan sosyal bulunuşluk ölçeğinin Cronbach $\alpha$ değerleri; ortak bulunuşluk için 0.79 , etkileme için 0.86 ve kaynaştırma için ise 0.91 'dir. Ölçeğin tamamı için hesaplanan Cronbach $\alpha$ değeri ise 0.94 'tür.

\section{Verilerin Analizi}

Öğrencilerin sosyal bulunuşluk algılarını yordayan öğrenme stratejilerini belirlemek için, adımsal (stepwise) regresyon analizi kullanılmıştır. Öğrencilerin sosyal bulunuşluk algılarının çeşitli değişkenlere göre anlamlı bir farklılık gösterip göstermediğini belirlemek için ise tek faktörlü varyans analizi kullanılmıştır.

\section{Bulgular}

Bu bölümde öncelikle sosyal bulunuşluğu yordayan öğrenme stratejilerini belirlemeye yönelik gerçekleştirilen regresyon analizi sonuçlarına yer verilmiştir. Bulgular öncelikle sosyal bulunuşluğun alt faktörleri için, ardından da sosyal bulunuşluk için verilmiştir. Son olarak da öğrencilerin sosyal bulunuşluk algılarının çeşitli değişkenlere göre anlamlı bir farklılık gösterip göstermediği incelenmiştir.

Bu bağlamda öğrencilerin sosyal bulunuşluk algılarını yordayan öğrenme stratejilerinin belirlenebilmesi için; yineleme, açımlama, düzenleme, eleştirel düşünme, üstbilişsel stratejiler, zaman ve çalışma ortamı yönetimi, emek yönetimi, akran işbirliği ve yardım isteme faktörleri analize katılmışıtır. Tablo 2 (ortak bulunuşluk), Tablo 3 (etkileme), Tablo 4 (kaynaştırma) ve Tablo 5 (sosyal bulunuşluk) yapılan adımsal regresyon analizlerinin sonuçlarını özetlemektedir.

Tablo 2. Öğrencilerin Ortak Bulunuşluk Algılarını Yordayan Değişkenler İçin Adımsal Regresyon Analizi Sonuçları

\begin{tabular}{llll}
\hline Model & $\mathrm{B}$ & $\mathrm{SE}_{\mathrm{B}}$ & $\beta$ \\
\hline Model 1 & .447 & .119 & $\begin{array}{l}.441 \\
\text { Düzenleme }\end{array}$ \\
& & & $\begin{array}{l}\mathrm{R}^{2}=.194 \\
\text { Düzeltilmiş } \mathrm{R}^{2}=.180 \\
\mathrm{R}=.441^{*}\end{array}$
\end{tabular}


Model 2

Düzenleme

$* \mathrm{p}<0.01$

Tablo 2 incelendiğinde, öğrencilerin ortak bulunuşluk algılarının; düzenleme ve yardım isteme stratejileri ile yordanabileceği görülmektedir. Diğer değişkenler, öğrencilerin ortak bulunuşluk algılarını yordamada önemli bir katkıda bulunmamıştır. İlk model öğrencilerin ortak bulunuşluk algılarının düzenleme stratejileri tarafından yordanabileceğini ve açıklanan varyansın \%19 olduğunu göstermektedir $\left(\mathrm{R}=.441, \mathrm{~F}_{(1,59)}=14.215, \mathrm{p}<.01\right)$. İlk modele yardım isteme stratejilerinin eklenmesi ile oluşan ikinci modelde açıklanan varyans yaklaşı olarak \%10 artmış ve böylece iki değişkenli modelin öğrencilerin ortak bulunuşluk algılarını yordamak için uygun olduğu sonucuna varılmıştır $\left(\mathrm{R}=.532, \mathrm{~F}_{(2,58)}=11.457, \mathrm{p}<.01\right)$.

Tablo 3. Öğrencilerin Etkileme Algılarını Yordayan Değişkenler İçin Adımsal Regresyon Analizi Sonuçları

\begin{tabular}{|c|c|c|c|}
\hline Model & B & $\mathrm{SE}_{\mathrm{B}}$ & $\beta$ \\
\hline \multicolumn{4}{|l|}{ Model 1} \\
\hline Düzenleme & .592 & .147 & $\begin{array}{l}.466 \\
\mathrm{R}^{2}=.217 \\
\text { Düzeltilmiş } \mathrm{R}^{2}=.204 \\
\mathrm{R}=.466^{*}\end{array}$ \\
\hline \multicolumn{4}{|l|}{ Model 2} \\
\hline Düzenleme & .474 & .153 & .372 \\
\hline Yardım isteme & .388 & .185 & .253 \\
\hline & & & $\begin{array}{l}\mathrm{R}^{2}=.272 \\
\text { Düzeltilmiş } \mathrm{R}^{2}=.247 \\
\mathrm{R}=.521 *\end{array}$ \\
\hline \multicolumn{4}{|l|}{ Model 3} \\
\hline Düzenleme & .668 & .170 & .525 \\
\hline Yardım isteme & .425 & .179 & .277 \\
\hline \multirow[t]{2}{*}{ Emek yönetimi } & -.419 & .182 & -.298 \\
\hline & & & $\begin{array}{l}\mathrm{R}^{2}=.334 \\
\text { Düzeltilmiş } \mathrm{R}^{2}=.299 \\
\mathrm{R}=.578 *\end{array}$ \\
\hline
\end{tabular}

$* \mathrm{p}<0.01$

Tablo 3 incelendiğinde, öğrencilerin etkileme algılarının; düzenleme, yardım isteme ve emek yönetimi stratejileri ile yordanabileceği görülmektedir. Diğer değişkenler, öğrencilerin etkileme algılarını yordamada önemli bir katkıda bulunmamıştır. İlk model öğrencilerin etkileme algılarının düzenleme stratejileri tarafından yordanabileceğini ve açıklanan varyansın $\% 22$ olduğunu göstermektedir $\left(\mathrm{R}=.466, \mathrm{~F}_{(1,59)}=16.330, \mathrm{p}<.01\right)$. İkinci model öğrencilerin etkileme algılarının düzenleme ve yardım isteme stratejileri tarafından yordanabileceğini ve açıklanan varyansın yaklaşık \%5 artışla \%27 olduğunu göstermektedir $\left(\mathrm{R}=.521, \mathrm{~F}_{(2,58)}=10.830, \mathrm{p}<.01\right)$. Son olarak üçüncü model öğrencilerin etkileme algılarının düzenleme, yardım isteme ve emek yönetimi stratejileri tarafindan yordanabileceğini ve açıklanan varyansın yaklaşık \%6 artışla \%33 olduğunu göstermektedir $(\mathrm{R}=.578$, $\left.\mathrm{F}_{(3,57)}=9.533, \mathrm{p}<.01\right)$. Sonuç olarak üç değişkenli modelin öğrencilerin etkileme algılarını yordamak için uygun olduğu sonucuna varılmıştır. 
Tablo 4. Öğrencilerin Kaynaştırma Algılarını Yordayan Değişkenler İçin Adımsal Regresyon Analizi Sonuçları

\begin{tabular}{|c|c|c|c|}
\hline Model & B & $\mathrm{SE}_{\mathrm{B}}$ & $\beta$ \\
\hline $\begin{array}{l}\text { Model } 1 \\
\text { Yardım isteme }\end{array}$ & .748 & .179 & $\begin{array}{l}.477 \\
\mathrm{R}^{2}=.228 \\
\text { Düzeltilmiş } \mathrm{R}^{2}=.215 \\
\mathrm{R}=.477 *\end{array}$ \\
\hline $\begin{array}{l}\text { Model } 2 \\
\text { Yardım isteme } \\
\text { Düzenleme }\end{array}$ & $\begin{array}{l}.556 \\
.431\end{array}$ & $\begin{array}{l}.182 \\
.151\end{array}$ & $\begin{array}{l}.355 \\
.332 \\
\mathrm{R}^{2}=.323 \\
\text { Düzeltilmiş } \mathrm{R}^{2}=.299 \\
\mathrm{R}=.568^{*}\end{array}$ \\
\hline $\begin{array}{l}\text { Model } 3 \\
\text { Yardım isteme } \\
\text { Düzenleme }\end{array}$ & $\begin{array}{l}.596 \\
.641\end{array}$ & $\begin{array}{l}.175 \\
.166\end{array}$ & $\begin{array}{l}.380 \\
.493\end{array}$ \\
\hline Emek yönetimi & -.452 & .177 & $\begin{array}{l}-.315 \\
\mathrm{R}^{2}=.392 \\
\text { Düzeltilmiş } \mathrm{R}^{2}=.360 \\
\mathrm{R}=.626^{*}\end{array}$ \\
\hline
\end{tabular}

$* \bar{p}<0.01$

Tablo 4 incelendiğinde, öğrencilerin kaynaştırma algılarının; yardım isteme, düzenleme ve emek yönetimi stratejileri ile yordanabileceği görülmektedir. Diğer değişkenler, öğrencilerin kaynaştırma algılarını yordamada önemli bir katkıda bulunmamıştır. İlk model öğrencilerin kaynaştırma algılarının yardım isteme stratejileri tarafından yordanabileceğini ve açıklanan varyansın $\% 23$ olduğunu göstermektedir $\left(\mathrm{R}=.477, \mathrm{~F}_{(1,59)}=17.389\right.$, $\mathrm{p}$ $<.01)$. İkinci model öğrencilerin kaynaştırma algılarının yardım isteme ve düzenleme stratejileri tarafından yordanabileceğini ve açıklanan varyansın yaklaşık $\% 9$ artışla $\% 32$ olduğunu göstermektedir $\left(\mathrm{R}=.568, \mathrm{~F}_{(2,58)}=\right.$ $13.824, \mathrm{p}<.01$ ). Son olarak üçüncü model öğrencilerin kaynaştırma algılarının yardım isteme, düzenleme ve emek yönetimi stratejileri tarafından yordanabileceğini ve açıklanan varyansın yaklaşık \%7 artışla \%39 olduğunu göstermektedir $\left(\mathrm{R}=.626, \mathrm{~F}_{(3,57)}=12.254, \mathrm{p}<.01\right)$. Sonuç olarak üç değişkenli modelin öğrencilerin kaynaştırma algılarını yordamak için uygun olduğu sonucuna varılmıştır.

Tablo 5. Öğrencilerin Sosyal Bulunuşluk Algılarını Yordayan Değişkenler İçin Adımsal Regresyon Analizi Sonuçları

\begin{tabular}{llll}
\hline Model & $\mathrm{B}$ & $\mathrm{SE}_{\mathrm{B}}$ & $\beta$ \\
\hline Model 1 & 1.640 & .390 & $\begin{array}{l}.480 \\
\mathrm{R}^{2}=.231 \\
\text { Düzenleme }\end{array}$ \\
& & & $\begin{array}{l}\text { Düzeltilmiş } \mathrm{R}^{2}=.218 \\
\mathrm{R}=.480^{*}\end{array}$ \\
Model 2 & & & .361 \\
Düzenleme & 1.232 & .398 & .324 \\
Yardım isteme & 1.337 & .480 & \\
& & & $\begin{array}{l}\mathrm{R}^{2}=.321 \\
\text { Düzeltilmiş } \mathrm{R}^{2}=.298 \\
\mathrm{R}=.567^{*}\end{array}$
\end{tabular}

Model 3 


\begin{tabular}{llll}
\hline Düzenleme & 1.752 & .440 & .513 \\
Yardım isteme & 1.436 & .463 & .348 \\
& & & \\
Emek yönetimi & -1.120 & .469 & -.297 \\
& & & $\mathrm{R}^{2}=.383$ \\
& & Düzeltilmiş $\mathrm{R}^{2}=.351$ \\
& & $\mathrm{R}=.619^{*}$ \\
\hline
\end{tabular}

$* \mathrm{p}<0.01$

Son olarak Tablo 5 incelendiğinde, öğrencilerin sosyal bulunuşluk algılarının; düzenleme, yardım isteme ve emek yönetimi stratejileri ile yordanabileceği görülmektedir. Diğer değişkenler, öğrencilerin sosyal bulunuşluk algılarını yordamada önemli bir katkıda bulunmamıştır. İlk model öğrencilerin sosyal bulunuşluk algılarının düzenleme stratejileri tarafından yordanabileceğini ve açıklanan varyansın \%23 olduğunu göstermektedir $(\mathrm{R}=$ $\left..480, \mathrm{~F}_{(1,59)}=17.687, \mathrm{p}<.01\right)$. İkinci model öğrencilerin sosyal bulunuşluk algılarının düzenleme ve yardım isteme stratejileri tarafından yordanabileceğini ve açıklanan varyansın yaklaşık \%9 artışla \%32 olduğunu göstermektedir $\left(\mathrm{R}=.567, \mathrm{~F}_{(2,58)}=13.741, \mathrm{p}<.01\right)$. Son olarak üçüncü model öğrencilerin sosyal bulunuşluk algılarının düzenleme, yardım isteme ve emek yönetimi stratejileri tarafından yordanabileceğini ve açıklanan varyansın yaklaşık \%6 artışla \%38 olduğunu göstermektedir $\left(\mathrm{R}=.619, \mathrm{~F}_{(3,57)}=11.800, \mathrm{p}<.01\right)$. Sonuç olarak üç değişkenli modelin öğrencilerin sosyal bulunuşluk algılarını yordamak için uygun olduğu sonucuna varılmıştır.

Öğrencilerin sosyal bulunuşluk ölçeğinden aldıkları puanların; cinsiyete, sınıfa ve bölüme göre anlamlı bir farklılık gösterip göstermediğini çözümlemek için ise ilişkisiz örneklemler için tek faktörlü varyans analizi kullanılmıştır. Yapılan analizlere ilişkin bulgular sırasıyla; Tablo 6, Tablo 7 ve Tablo 8'de sunulmuştur.

Tablo 6. Öğrencilerin Sosyal Bulunuşluk Ölçeğinden Aldıkları Puanların Cinsiyete Göre ANOVA Sonuçları

\begin{tabular}{lccccc}
\hline Varyansin & Kareler & sd & Kareler Ortalamas1 & F & p \\
Kaynağ1 & Toplamı & & & & .785 \\
Gruplararası & 20.464 & 1 & 20.464 & .075 & \\
Gruplariçi & 16060.552 & 59 & 272.213 & & \\
Toplam & 16081.016 & 60 & & & \\
\hline
\end{tabular}

Tablo 7. Öğrencilerin Sosyal Bulunuşluk Ölçeğinden Aldıkları Puanların Sınıfa Göre ANOVA Sonuçları

\begin{tabular}{lccccc}
\hline Varyansın Kaynağı & Kareler Toplamı & $\mathrm{sd}$ & Kareler Ortalaması & $\mathrm{F}$ & $\mathrm{p}$ \\
Gruplararası & 65.879 & 1 & 65.879 & .243 & .624 \\
Gruplariçi & 16015.137 & 59 & 271.443 & & \\
Toplam & 16081.016 & 60 & & & \\
\hline
\end{tabular}

Tablo 8. Öğrencilerin Sosyal Bulunuşluk Ölçeğinden Aldıkları Puanların Bölüme Göre ANOVA Sonuçları

\begin{tabular}{lccccc}
\hline Varyansın Kaynağı & Kareler Toplamı & sd & Kareler Ortalaması & F & p \\
Gruplararası & 673.591 & 1 & 673.591 & 2.579 & .114 \\
Gruplariçi & 15407.426 & 59 & 261.143 & & \\
Toplam & 16081.016 & 60 & & & \\
\hline
\end{tabular}

Analizlere ilişkin olarak, Tablo 6, Tablo 7 ve Tablo 8'de görüldüğü üzere, öğrencilerin sosyal bulunuşluk ölçeğinden aldıkları puanlar arasında, cinsiyete $\left[\mathrm{F}_{(1-59)}=.075, \mathrm{p}>.05\right]$, sınıfa $\left[\mathrm{F}_{(1-59)}=.243\right.$, p>.05] ve bölüme $\left[\mathrm{F}_{(1-}\right.$ 59) $=2.579, \mathrm{p}>.05]$ göre anlamlı bir farklılık yoktur. Diğer bir ifadeyle, öğrencilerin sosyal bulunuşluk ölçeğinden aldıkları puanlar; cinsiyete, sınıfa ve bölüme göre değişmemektedir.

\section{Tartışma ve Sonuç}

Araştırma sonuçları öğrencilerin ortak bulunuşluk algılarının; düzenleme ve yardım isteme ile, etkileme algılarının; düzenleme, yardım isteme ve emek yönetimi ile, kaynaştırma algılarının; yardım isteme, düzenleme ve emek yönetimi ile ve son olarak sosyal bulunuşluk algılarının ise; düzenleme, yardım isteme ve emek yönetimi ile yordanabileceğini göstermiş̧tir. Ayrıca öğrencilerin sosyal bulunuşluk algıları; cinsiyet, sınıf ve bölüm değişkenlerine göre anlamlı bir farklılık göstermemiştir. 
Öğrencilerin sosyal bulunuşluğun alt faktörleri ile ilgili algılarını ve sosyal bulunuşluk algılarını yordayan öğrenme stratejilerinin yorumlanabilmesi, sosyal bulunuşluğun alt faktörlerinin ne anlama geldiğinin bilinmesi ile daha iyi anlaşılacaktır. Araştırma kapsamında kullanılan sosyal bulunuşluk ölçeğinin üç alt faktörü Olpak ve Kılı̨̧ Çakmak (2009) tarafından aşağıdaki şekilde tanımlanmıştır.

- Ortak bulunuşluk; bireylerin kendini grubun bir parçası gibi görmesini ve grubun dışında hissetmemesini, bireylerin birbirlerini dikkate almalarını ve birbirlerinden haberdar olmalarını,

- Etkileme; bireylerin birbirlerini anlamalarını, birbirlerinden bağımsız olarak fikirler ileri sürebilmelerini ve birbirlerine yardım etmelerini,

- Kaynaştırma ise; bireylerin olumlu yönde etkileşime girmelerini, yapılan çalışmalara katk1 sağlama şansı bulmalarını ve kendilerini gruba ait hissetmelerini ifade etmektedir.

Düzenleme stratejileri uygun bilgiyi seçme ve öğrenilecek bilgiyi, bilgiler arası bağlantıları kurarak yapılandırmada öğrencilere yardımcı stratejilerdir (Pintrich ve diğerleri, 1991). Paragrafların anafikrini bulmak düzenleme stratejilerine örnek gösterilebilir. Düzenleme stratejileri belirtilen bu özelliklerinden dolayı öğrencilerin sosyal bulunuşluğun alt faktörleri ile ilgili algılarını ve sosyal bulunuşluk algılarını yordamış olabilir.

Yardım isteme stratejileri ise, gerektiğinde yardım alma gereğini belirleyebilme ve yardım isteme ile ilgili stratejilerdir (Pintrich ve diğerleri, 1991). Bu bağlamda diğer öğrencilerden veya öğretim elemanından yardım istenebilir. Öğrencilerin gerektiğinde yardım alabilmeleri için; telefon, sohbet (chat), e-posta ve video ortamlarından biri veya birkaçı sunulabilir. Böylece, herhangi bir sorunla karşılaştıklarında yalnız olmadıklarını, kendilerine yardım edecek birilerinin olduğunu bilirler (Lehman ve Conceição, 2010). Yardım isteme stratejileri de, belirtilen bu özelliklerinden dolayı, öğrencilerin sosyal bulunuşluğun alt faktörleri ile ilgili algılarını ve sosyal bulunuşluk algılarını yordamış olabilir.

Emek yönetimi stratejileri ise, öğrencilerin verilen bir görevde dikkatini ve çabasını sürdürmesini sağlayan stratejilerdir. Öğrenme stratejilerinin kullanımının devam ettirilmesini ve zor görev ve konularda çalışmaya devam edilmesini sağladığından akademik başarı için önemlidir (Pintrich ve diğerleri, 1991). Öğrencilerin birbirleriyle fikir alışverişinde bulunabilecekleri işbirlikli öğrenme etkinlikleri, öğrenci-öğrenci etkileşimini artırarak sosyal bulunuşluk algısını artırabilir (Rovai, 2000, 2002; Whiteman, 2002). Ancak grup çalışmaları, grup tartışmaları, beyin firtınası oturumları, grup görevleri, grup projeleri ve çevrimiçi grup tartı̧ması gibi öğrenme etkinlikleri; sosyal bulunuşluk algısını artırmak için önceden düzgün bir şekilde planlanmalıdır (Vrasidas ve McIsaac, 2000). Bu bağlamda emek yönetimi stratejileri belirtilen bu özelliklerinden dolayı öğrencilerin sosyal bulunuşluğun alt faktörlerinden etkileme ve kaynaştırma ile ilgili algılarını ve sosyal bulunuşluk algılarını yordamış olabilir.

$\mathrm{Bu}$ araştırmanın katılımcılarını bir devlet üniversitesinde bulunan uzaktan eğitim meslek yüksekokulunda öğrenim gören öğrenciler oluşturmaktadır. Bu nedenle, araştırma bulgularının genellenebilmesi için, farklı uzaktan eğitim meslek yüksekokullarında öğrenim gören öğrencilerin de yer aldığı, daha geniş kapsamlı araştırmalar yapılması önerilmektedir. Ayrıca araştırmacılar her öğrenim seviyesinde öz düzenlemenin öneminden bahsetmektedirler. Çünkü öz-düzenleme becerisine sahip olan öğrencilerin; bilişsel farkındalıklarının ve özyeterlik düzeylerinin yüksek olduğu, hedef planlamalarını iyi yaptıkları, etkili bir zaman ve emek yönetimi gerçekleştirdikleri görülmektedir. Bu bağlamda ileride yapılacak araştırmalarda; farklı eğitim düzeylerindeki (önlisans, lisans ve lisansüstü gibi) öğrencilerin de yer aldığı çalışmaların yapılması, konuyla ilgili daha derin bilgi sahibi olunmasını sağlayacağından önemli görülmektedir. 


\section{References}

Anderson, T., \& Garrison, D. R. (1995). Critical thinking in distance education: Developing critical communities in an audio teleconference context. Higher Education, 29(2), 183-199.

Büyüköztürk, SS., Akgün, Ö. E., Özkahveci, Ö., \& Demirel, F. (2004). Güdülenme ve öğrenme stratejileri ölçeğinin Türkçe formunun geçerlik ve güvenirlik çalışması [The validity and reliability study of the Turkish version of the motivated strategies for learning questionnaire]. Kuram ve Uygulamada Ĕgitim Bilimleri[Educational Sciences: Theory \& Practice], 4(2), 207-239.

Corno, L. (2001). Volitional aspects of self-regulated learning. In B. J. Zimmerman, \& D. H. Schunk (Eds.), Self-regulated learning academic achievement: Theoretical perspectives (pp. 191-225). Hillsdale, NJ: Erlbaum.

Garrison, D. R. (1991). Critical thinking and adult education: A conceptual model for developing critical thinking in adult learners. International Journal of Lifelong Education, 10(4), 287-303.

Garrison, D. R. (2000). Theoretical challenges for distance education in the 21st century: A shift from structural to transactional issues. The International Review of Research in Open and Distance Learning, 1(1).

Garrison, D. R. (2009). Communities of inquiry in online learning. In P. Rogers (Ed.), Encyclopedia of Distance Learning (2nd ed., pp. 352-360). IGI Global.

Gunawardena, C. N., \& Zittle, F. J. (1997). Social presence as a predictor of satisfaction within a computermediated conferencing environment. American Journal of Distance Education, 11(3), 8-26.

Harasim, L. M. (1990). Online education: Perspectives on a new environment. Greenwood Publishing Group Inc..

Henri, F., \& Rigault, C. R. (1996). Collaborative distance learning and computer conferencing. In In Advanced Educational Technology: Research Issues and Future Potential (pp. 45-76). Springer Berlin Heidelberg.

Holmberg, B. (1991). The feasibility of a predictive theory of distance education: What are we allowed to expect. In B. Holmberg \& G.Ortner (Eds.), Research Into Distance Education.

Kang, M., Choi, H., \& Park, S. (2007). Construction and validation of a social presence scale for measuring online learners' involvement. In World Conference on Educational Multimedia, Hypermedia and Telecommunications, 2007(1), 1829-1833.

Katz, Y. J. (2000). The comparative suitability of three ICT distance learning methodologies for college level instruction. Educational Media International, 57(1), 25-30.

Kim, J., Kwon, Y., \& Cho, D. (2011). Investigating factors that influence social presence and learning outcomes in distance higher education. Computers \& Education, 57(2), 1512-1520.

Lehman, R. M., \& Conceição, S. C. O. (2010). Creating a sense of presence in online teaching: How to " be there" for distance learners. San Francisco:Jossey-Bass.

Lowenthal, P. R., \& Dunlap, J. C. (2010). From pixel on a screen to real person in your students' lives: Establishing social presence using digital storytelling. Internet and Higher Education, 13(1), 70-72.

Lu, Y., Huang, W., Ma, H., \& Luce, T. (2007). Interaction and social presence in technology-mediated learning: A partial least squares model. In In Wireless Communications, Networking and Mobile Computing, 2007. WiCom 2007. International Conference on (pp. 4411-4414). IEEE.

Montalvo, F. T., \& Torres, M. C. G. (2004). Self-regulated learning: Current and future directions. Electronic Journal of Research in Educational Psychology, 2(1), 1-34.

Moore, M. G. (1993). Theory of transactional distance. In D. Keegan (Ed.), Theoretical Principles of Distance Education (pp. 20-35). Routledge.

Moore, M. G., \& Anderson, W. G. (2003). Handbook of distance education. Routledge.

Moore, M. G., \& Kearsley, G. (1996). Distance Education: A Systems View of Online Learning, 3rd ed.: A 
Systems View of Online Learning. Toronto:Wadsworth.

Olpak, Y. Z., \& Kılıç Çakmak, E. (2009). E-öğrenme ortamları için sosyal bulunuşluk ölçeğinin uyarlama çalışması [Assessing social presence in e-learning environments: Validity and reliability analysis]. Yüzüncü Yıl Üniversitesi Eğitim Fakültesi Dergisi [Yüzüncü Yıl University Journal of Education Faculty], 6(1), 142160.

Oxford, R. (1990). Language learning strategies: What every teacher should know. Boston. Heinle \& Heinle Publishing.

Pintrich, P. R. (1995). Understanding self-regulated learning. In P. R. Pintrich (Ed.), Understanding selfregulated learning (pp. 3-12). San Francisco: Jossey-Bass.

Pintrich, P. R. (2000). The role of goal orientation in self-regulated learning. In M. Boekaerts, P. R. Pintrich, \& M. Zeidner (Eds.), Handbook of self-regulation (pp. 451-502). San Diego, CA: Academic Press.

Pintrich, P. R., \& De Groot, E. V. (1990). Motivational and self-regulated learning components of classroom academic performance. Journal of Educational Psychology, 82(1), 33-40.

Pintrich, P. R., Smith, D. A. F., Garcia, T., \& McKeachie, W. J. (1991). A manual for the use of the motivated strategies for learning questionnaire (MSLQ). Retrieved from http://eric.ed.gov/?id=ED338122

Richardson, J. C., \& Swan, K. (2003). Examining social presence in online courses in relation to students' perceived learning and satisfaction. Journal of Asynchronous Learning Networks, 7(1), 68-88.

Rourke, L., Anderson, T., Garrison, D. R., \& Archer, W. (2001). Assessing social presence in asynchronous textbased computer conferencing. The Journal of Distance Education / Revue de l'Éducation À Distance, 14(2), $50-71$.

Rovai, A. P. (2000). Building and sustaining community in asynchronous learning networks. Internet and Higher Education, 3(4), 285-297.

Rovai, A. P. (2002). Building sense of community at a distance. The International Review of Research in Open and Distance Learning, 3(1).

Saba, F., \& Shearer, R. L. (1994). Verifying key theoretical concepts in a dynamic model of distance education. American Journal of Distance Education, 8(1), 36-59.

Schunk, D. H., \& Zimmerman, B. J. (2008). Motivation and self-regulated learning: Theory, research and applications. New York: Routledge.

Shen, D., Nuankhieo, P., Huang, X., Amelung, C., \& Laffey, J. (2008). Using social network analysis to understand sense of community in an online learning environment. Journal of Educational Computing Research, 39, 17-36.

Short, J., Williams, E., \& Christie, B. (1976). The social psychology of telecommunications. New York: John Wiley \& Sons.

Soo, K. S., \& Bonk, C. J. (1998). Interaction: What does it mean in online distance education?. Retrieved from http://www.eric.ed.gov/ERICWebPortal/recordDetail?accno=ED428724

Swan, K., \& Shih, L. F. (2005). On the nature and development of social presence in online course discussions. Journal of Asynchronous Learning Networks, 9(3), 115-136.

Tu, C.-H., \& McIsaac, M. (2002). The relationship of social presence and interaction in online classes. American Journal of Distance Education, 16(3), 131-150.

Vrasidas, C., \& McIsaac, M. S. (2000). Principles of pedagogy and evaluation for web-based learning. Educational Media International, 37(2), 105-111.

Weinstein, C. E., Husman, J., \& Dierking, D. R. (2000). Self-regulation interventions with a focus on learning strategies. In M. Boekaerts, P. R. Pintrich, \& M. Zeidner (Eds.), Handbook of self-regulation (pp. 728-748), San Diego, CA: Academic Press. 
Weinstein, C. E., \& Mayer, R. E. (1986). The teaching of learning strategies. In M. C. Wittrock (Ed.), Handbook of research on teaching (3rd ed.), (pp. 315-327). New York: MacMillan Company.

Whiteman, J. A. M. (2002). Interpersonal communication in computer mediated learning. Retrieved from http://www.eric.ed.gov/ERICWebPortal/search/detailmini.jsp?_nfpb=true\&_\&ERICExtSearch_SearchValue _0=ED465997\&ERICExtSearch_SearchType_0=no\&accno=ED465997

Winn, W. (1999). Learning in virtual environments: A theoretical framework and considerations for design. Education Media International, 36(4), 271-279.

Winne, P. H. (1995). Inherent details in self-regulated learning. Educational Psychologist, 30, 173-187.

Zimmerman, B. J. (1990). Self-regulated learning and academic achievement: An overview. Educational Psychologist, 25(1), 3-17.

Zimmerman, B. J. (1998). Developing self-fulfilling cycles of academic regulation: An analysis of exemplary instructional model. In D. H. Schunk, \& B. J. Zimmerman (Eds.), Self-regulated learning: From teaching to self-reflective practice (pp. 1-19). New York: Guilford.

Zimmerman, B. J. (2000). Attaining self-regulation: A social cognitive perspective. In M. Boekaerts, P. R. Pintrich, \& M. Zeidner (Eds.), Handbook of self-regulation (pp. 451-502). San Diego, CA: Academic Press

Zimmerman, B. J. (2001). Achieving academic excellence: A Self-regulatory perspective. In M. Ferrari (Ed.), The pursuit of excellence through education (pp. 85-110). Mahwah, NJ: Erlbaum.

Zimmerman, B. J. (2002). Becoming a self-regulated learner: An overview. Theory into Practice, 41, 64-72. 